論

\title{
遠赤外線放射体の作製と各種加熱形態による人体の保温性の比較
}

\author{
非会員 田口春 男 (TDK 株式会社) 非会員 水戸部一孝（秋田大学） 正会員 吉 村 昇 (秋田大学)
}

\section{Fabrication of Far Infrared Rays Radiation Body and Consideration of the Heat Retention on Human in Comparison with Other Properties}

Non member Haruo Taguchi (TDK),

Non member Kazutaka Mitobe (Akita University) and

Member Noboru Yoshimura (Akita University)

\begin{abstract}
The purpose of this study is to examine the effect of Far Infrared Rays radiation body. Natural Zeolite was reported as having excellent characteristics for manufacturing FIR radiation body. So we manufactured FIR radiation body using the following procedure: we used the burned powder of natural zeolite and a heat resistant binding agent to produce FIR paint; and then we applied the FIR paint to an aluminum plate. The FIR radiation body did not shed from the aluminum plate, and it had a high emission rate of greater than $80 \%$ at a wavelength of 5 to 25 micrometers. In addition, to investigate the difference of heat retention of the human body, we compared the temperature distribution of a FIR radiation heater, a thermal conduction heater, and a convection heater when applied to a human hand.
\end{abstract}

KEYWORDS : Far Infrared Rays radiation, human body, heat retention, natural zeolite

\section{1.はじめに}

遠赤外線は赤外線の一種である。遠赤外線による加熱は空気な ぞによる途中媒体によるエネルギー損失が少なく，有機物などを 効果的に加熱できるため，フォ一ド社が自動車塗装の乾燥に用い て以来, 暖房機器, 温熱療法の医療機器等, 種々用途に利用され ている ${ }^{1)}$.一方，黑体に近い分光放射率を有寸る材料として天然ゼ オライトを原料としたセラミクスが報告されている2).また, 天然 ゼオライトを原料としたセラミクスを遠赤外線放射体として用い ると $\mathrm{TiO}_{2} や \mathrm{Al}_{2} \mathrm{O}_{3}$ セラミクスに比べ寒犬の加熱効率が享いとの 報先が女る ${ }^{3)}$ 。これは天然ゼオライトを原料としたセラミクスの 分光放射率が, 水の吸収波長域（主に $3 \mu \mathrm{m}$ 抢よび $6 \mu \mathrm{m}$ )で高く, 効率よく加熱できるからであるとされている1). ところが, セラミ クスは成形に大きな压力が必荘であり，焼成時の収縮や変形のた め広い面積のものが作製しにくい，さらに，加熱時に温度の不均 一により割れやすく，使用しにくいといった欠点がある。

本研究では医療への芯用を視野に置き, 面積の広い高分光放射 率遠赤外線放射体を安価で簡便に作製古る方法の構築を目的とし た。また，人体に対守る遠赤外線加熱の効果については十分には 調べられていない。そこで熱伝達形態の違いによる保温性の相違 を明らかにするために, 遠赤外線放射加熱後の人体の温度変化を 調へ， 熱伝導加熱, 熱対流加熱との比較検討を試みた。

\section{2. 遠赤外線放射体の作製とその放射特性}

\section{1 分光放射率測定方法}

本研究では光学的骞位法を原理とする赤外分光光度計（島津製 作所 IR-435型）基本とした装置で，遠赤外線放射体の分光放射 率老測定した。その測定系を図 1 に示古。本装置は標準光源とし て温度コントローラーを備えた黒体炬（Shimaden 製，SR-22）を 用いている，放射体を設置，加熱する試料ホル夕゙には放射体表面 の放射面積を一定にする役割を持つ直径 $10 \mathrm{~mm}$ の空が設けてある。 ホルダの加熱ヒ一夕に印加㐫る電圧はスライダックによって調節 し，発生熱量をコントロールした。放射体の表面温度は，熱電刘 （CA）とマルチメータ（アドバンテスト製，TR2114）で测定し た。試料表面からの放射は 4 枚のミラーによって分光光度計分光 器部に導かれ，ここで同じように導かれた黑体炉の放射と比較し た.分光光度計出力部には黒体炉の放射強度を $100 \%$ としたときの 試料表面の放射強度が表示される。本装置の分光光度計は熱電計 の検出器を用いているために，その性能を生かすには入射光の工 ネルギーをある程度大きくする必要がある。本研究では装置の忘 答性などを考虑して黒体炉内部と試料表面の温度を $400^{\circ} \mathrm{C}$ に設定 して測定を行った．以下，この装置を遠赤外線測定装置と称与る。 なお，本装置では $4000 \mathrm{~cm}^{-1} \sim 400 \mathrm{~cm}^{-1}(2.5 \mu \mathrm{m} \sim 25 \mu \mathrm{m})$ の領域で測 定が可能である. 


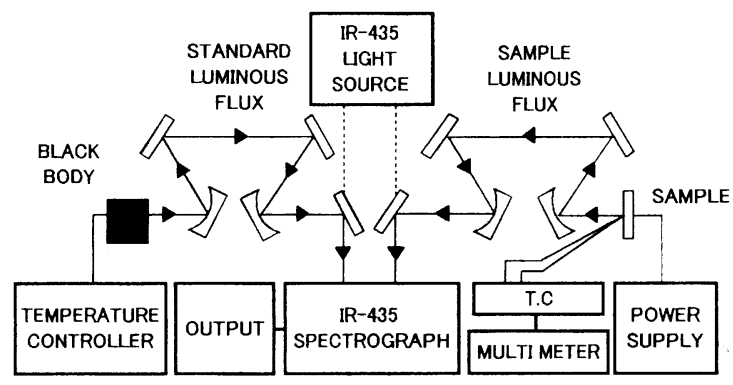

図 1 分光放射率測定装置

Fig. 1 Spectral emissivity measuring system.

\section{2 遠赤外線放射材料および遠赤外線放射体作製方法}

ゼオライトはSiの相当量を $\mathrm{Al}$ で置換しているアルミノ珪酸 塩の 1 種である4). ゼオライトは空润構造老もち吸着性およびイ オン交換性があるため土堙改良剂, 吸着剂, 水質の湃化材などの 用途として利月されている。现在では天然鉱物として40種以上， 合成ゼオライトとして150種以にが知られている。然ゼオライト は日本のみならず，世界各国に賦存しているが，地層のわずかな 物理的, 化学的条件の違いによって結晶構造と化学組成の買なる ゼオライト種が産出する ${ }^{5}$. また, 天然物であるため鿽命的に夾雑 物を含んでいる。本研究ではクリノプチロライトを主として， $\alpha$ クオーツ, 长石, $\alpha$ 一クリスドライトを不純物として含む秋田県 二.ツ井町の天然ゼオライト（サンゼオライト製，製品名3S，平均 粓径 $6 \mu \mathrm{m}$ ) を原料粉木として使用した。組成は, $\mathrm{SiO}_{2}$ 69.4重星 $\%, \mathrm{Al}_{2} \mathrm{O}_{3}$ 11重昌\%, $\mathrm{Fe}_{2} \mathrm{O}_{3} \quad 0.9$ 重 $\%$, $\mathrm{CaO}$ 1.3重早\%, $\mathrm{MgO}$ 0.6 重量\%, $\mathrm{Na}_{2} \mathrm{O} 3$ 重量\%, $\mathrm{K}_{2} \mathrm{O} 3.2 \%$ である ${ }^{6}$. 以下これを

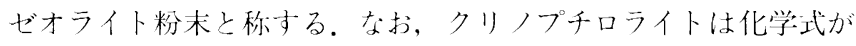
$\mathrm{Ca}(\mathrm{Na}, \mathrm{K})_{4} \cdot \mathrm{Al}_{6} \cdot \mathrm{Si}_{30} \cdot \mathrm{O}_{72} \cdot 24 \mathrm{H}_{2} \mathrm{O}$ で与之られる。

一お，パーライトは流紋览質のガラス質火川岩であり真珠岩と も言われている。産地として秋出県, 福島県, 長野県などが知ら れている》。本研究では秋川県森古盯産出のパーライト(東興パー ライト(林㢼〉の粉木を原料とした。なお，半均粒径は $6 \mu \mathrm{m}$, 組成 は, $\mathrm{SiO}_{2} 75.3$ 重量\%, $\mathrm{Al}_{2} \mathrm{O}_{3}$ 13.4重量\%, $\mathrm{Fe}_{2} \mathrm{O}_{3}$ 1.1重望\%, $\mathrm{K}_{2} \mathrm{O} 4.9$ 重量\%, 他であった。以下，己れをパーライト粉末と称 守る。

遠赤外線放射体の作製方法は以下の通りである。ゼオライト粉 末の $1100^{\circ} \mathrm{C}$ 熱処理品と耐熱性バインダー (Ceramabond571： Aremco products, inc) を混合することでペースト状にする。こ れを $30 \times 30 \mathrm{~mm}$ のアルミニウム板に塗布し $24 \mathrm{~h}$ 室温乾燥させる。な

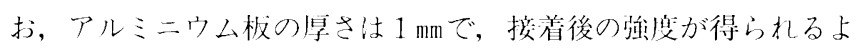
うに40番の紙やすりで染布面に山凸をつけた。その後, 具空引き 军ることで捙発性成分を充分取り除いた後, $130^{\circ} \mathrm{C} 3 \mathrm{~h}$ 熱処理で固 化，接着させる。こうしてできた遠赤外線放射体を前述の遠赤外 線測定装置により分光放射率を测定した。また，パーライト粉末 もゼオライト粉木と同様の方法で遠赤外線放射体を作り分光放射 率を测定した。

\section{3 遠赤外線分光放射特性}

図 2 に遠赤外線放射体の分光放射率を示す。横軸は波数および 波長, 縦軸は分光放射率索示。グラフの点線は, ゼオライト粉 木を原材料とした放射体の分光放射率である。破線は，パーライ 卜を原材料とした放射体の分光放射率である。さらに実線は両者 を混合した放射体の分光放射率である。ゼオライト粉末， $1100^{\circ} \mathrm{C}$ 熱処理品の分光放射率は $8 \sim 10 \mu \mathrm{m}$ で $\mathrm{Si}^{-} \mathrm{O}$ 結合の拢動に関連文

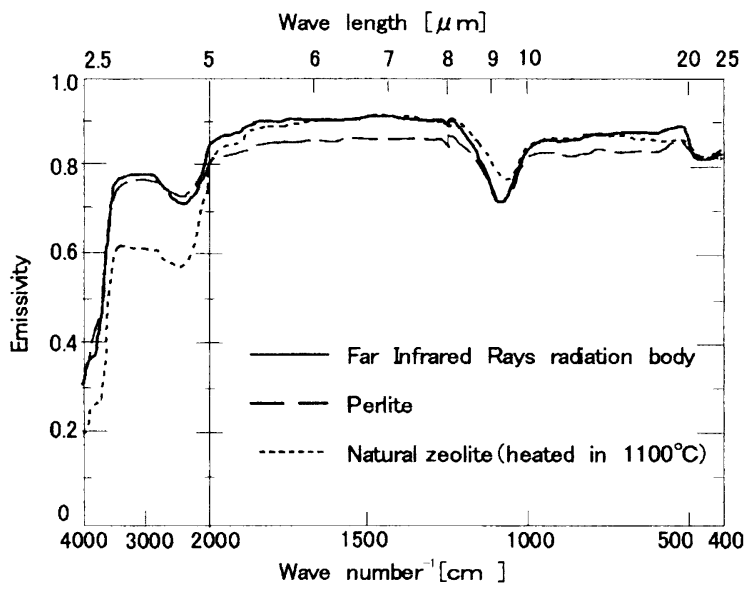

図2 遠赤外線放射体分光放射率

Fig. 2 Far infrared rays radiation body spectral emissivity.

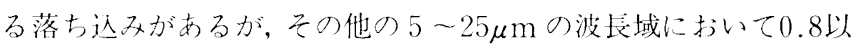
にと高放射率である。しかし，欠点として人体の構成要素である 水の吸収波長域を含吉，知波長側の $2.5 \sim 5 \mu \mathrm{m}$ では0.8以下と低如 であり改善の余地があった。また，その波長域は遠赤外線加熱に 適する $400^{\circ} \mathrm{C} \sim 500^{\circ} \mathrm{C}$ の溫度に扔いて分光放射発散度のピークがあ るため加熱効摔の上で重要となる。パーライト粉本は，ゼオライ 卜粉木に比べ $5 \sim 25 \mu \mathrm{m}$ での分光放射率が劣るものの, $2.5 \mu \mathrm{m}$

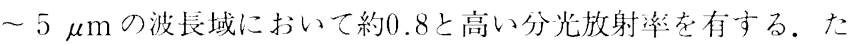
だしパーライト粉末単体では放射体作製将に，ゼオライト粉木で は胃られない発泡を生じ，表面が粗く脆いという久点があった。

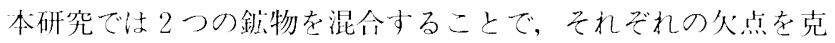
服することを試みた。結果, ゼオライト粉本とパーライト粉术 2 ： 1の混合物と耐熱性:バイン゙ーを10：7の重量比で混合すること により，企般に高放射率で，発泡を抑之た強固な放射体考作製卞 ることが叮能となった。なお，それぞれの条件で評価倣射体は 5 枚作製したが, 分光放射率にばらつきは見られなかった。また， アルミ二ウム板上:に形成された遠赤外線放射体の厚みは $100 \mu \mathrm{m}$ 〜 $150 \mu \mathrm{m}$ であり卜地アルミ二ウムの赤外線放射の透過による影 響はないと考えられる。

以上のように宛価な天然鋌物であるゼオライトとパーライトを 原料としており，また，粉末を金属板に塗布，接着寸る方法のた め，七ラミクスよりも簡使に，面樍の公い放放射率邀赤外線放射

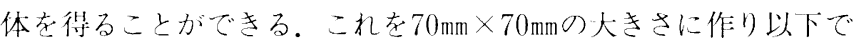
の加熱実験用遠亦外線放射体とした。

\section{3. 生体加熱実験装置および実験方法}

遠赤外線放射，熱伝堭等対流の各熱伀详形態による人体の保 温性への影剩老調べるため, 図 3 に示子加熱実験装㯰を構成した。 なお，被加熱部位として手掌を巽んだのは，普段から露出してい るため室温と平衡状態にあり测定が容易で，末梢のため毛細血管 が豊富で保温効果の差異が現れや一いことが期待できたからであ る。遠赤外線放射による加熱実験では㓩出の遠赤外線放射体を平 型板状七一夕(定格 $300 \mathrm{~W}$ ) と密着させ遠赤外線七一夕を構成した.

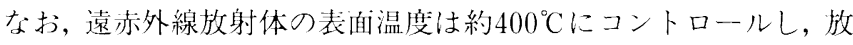
射面積を一定とするために直径 $40 \mathrm{~mm}$ の空を設けた水冷遮蔽板を通 して遠赤外線放射を行った。また，遠赤外線放射体と手掌部の距 離は, 遠赤外線放射のみの加熱とみなせるように $80 \mathrm{~mm}$ 離している。 熱伝導による加熱実験では鉄製容器に $40^{\circ} \mathrm{Cに}$ 維持した晹を入れ， 


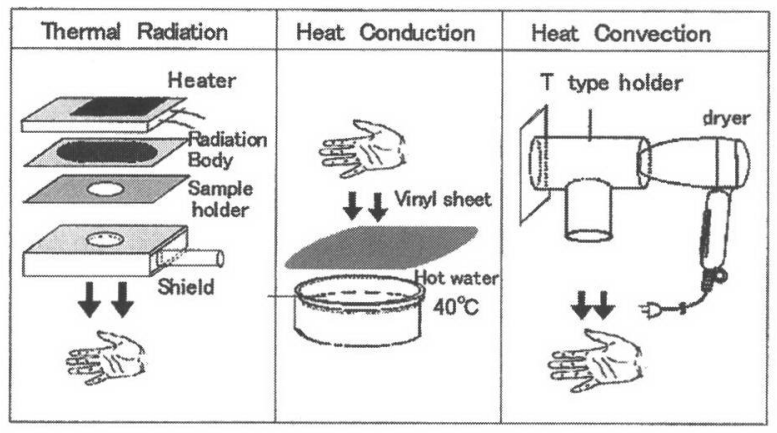

図 3 実験装置

Fig. 3 Experimental system.

手が濡れないように水面にビニールシートを敷き，手掌部全体が ビニールシートに触れるように接触させた。熱対流による加熱実 験では熱源として1200Wのへアドライヤを用いた。なお，二クロ ム線からの赤外放射を遮るために吹き出し口に $\mathrm{T}$ 字型の筒型ホル ダを取り付け，温風のみが手掌にあたるようにした。実験は室温 $19^{\circ} \mathrm{C}$ の部屋で行った．被験者は30分以上同じ環境の部屋で待機し ており充分順応している. 加熱はどの熱伝達形態でも手掌部の温 度が約 $40^{\circ} \mathrm{C}$ に達し安定する 6 分間行い, 各伝達形態で $40^{\circ} \mathrm{C} \pm 1{ }^{\circ} \mathrm{C}$ になるように加熱条件を調節している，手掌は肘を机などに固定 して加熱源からの距離や接触が一定になるように工夫している。 加熱時は 3 分おきに, 加熱停止後は 2 分扮きにサーマルカメラ (日 本アビオニクス製 TVS-620)を用いて手掌の温度を計測した。な お, 被験者は 20 代の男性 5 名であり, 測定回数は 1 人 1 回である.

\section{4. 実験結果}

図 4 に, 代表例として被験者の一人の各熱伝達形態における加 熱停止直後と停止 6 分後での手掌部のサーマルカメラ画像を示 す. 遠赤外線放射の場合, 加熱停止直後では放射空の形の影響を 受け部分的な加熱状態となっている. しかし, 加熱停止 6 分後の 画像では他の熱伝達形態に比べ, 手掌全体で温度が高く保温性に 優れることがわかる. 一方, 熱対流による加熱では, 加熱停止直 後は温度が高いが加熱停止 6 分後には指先の温度が低下している

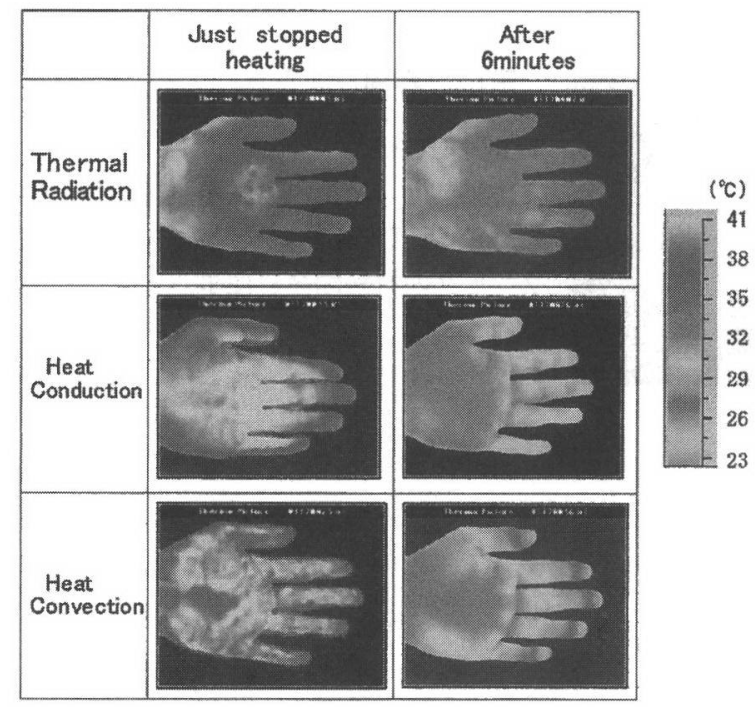

図 4 加熱時および加熱停止後の手掌温度分布

Fig. 4 Distribution of temperature in human hand.

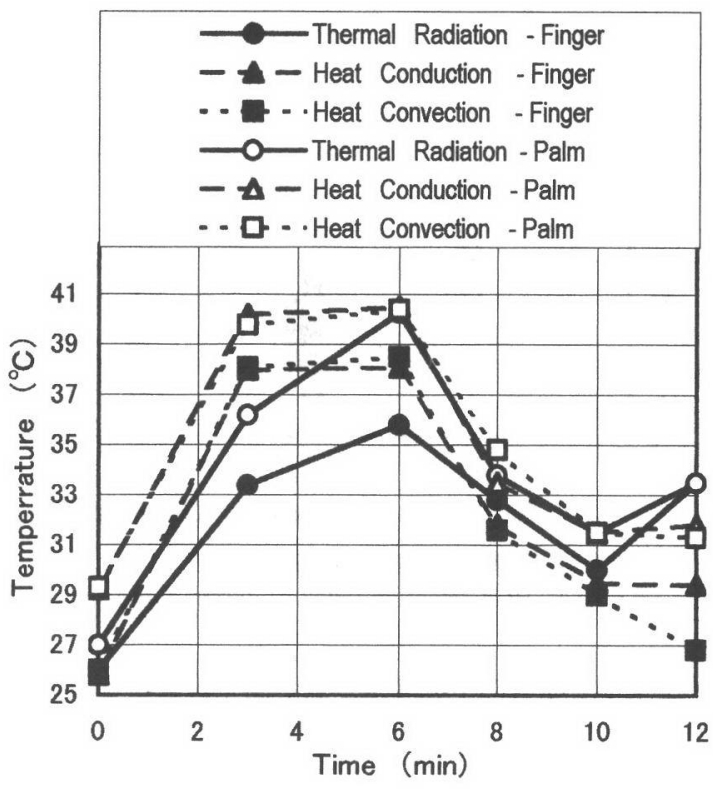

図 5 指と手掌の温度変化

Fig. 5 Temperature change of huran hand.

のが見て取れ，保温性に劣ることがわかる，

さらに, サーマルカメラ画像のデータを定量的に表すため, 被 験者の手掌部㧈よび指先部の温度を次のように算出した。指先部 温度は各指腹中央部 5 点の平均值から求めた。 また, 手掌部温度 は, (AVIONICS 製) TVR 温度分布処理ソフトウェアを用いて, 遠赤外線放射加熱時では加熱中心である直径 $40 \mathrm{~mm} の$ 範囲における 平均温度を算出した. 他の熱伝達形態での手掌部平均温度も同様 に, 同位置の同面積における平均温度を算出している。図 5 に, 手掌部と指先部の温度の経時変化を示寸。横軸は, 加熱開始から の経過時間, 縦軸は温度を示す. 白抜き印は手掌部の温度, 塗り つぶした印は指先部の温度を示す。また, 実線で丸印は遠赤外線 放射加熱, 破線で三角印は熱伝導加熱, 点線で四角印は熱対流加 熱を表す。各熱伝達形態で手掌部の温度は, 指腹部よりも高い。 また，遠赤外線放射加熱の温度上昇は他の加熱上りも緩やかであ $\eta$, 遠赤外線放射加熱停止後の指先の温度低下は緩やかである. 加熱停止後 6 分において, 遠赤外線放射加熱の手掌および指先の 温度が上昇している点については現在のところ不明である。なお， 他の 4 人でも同様傾向の, サーマルカメラ画像と手掌部および指 先部の温度の経時変化デー夕が得られている.

また, 保温性を定量化するために次式の保温指標值 $R$ を定義す る.

$R=\left(T_{\mathrm{b}}-T_{\mathrm{o}}\right) /\left(T_{\mathrm{a}}-T_{\mathrm{o}}\right)$

ここで $R$ : 保温指標值 $T_{\mathrm{o}}$ : 加熱前温度 $T_{\mathrm{a}}$ : 加熱後温度 $T_{\mathrm{b}}$ : 加熱停止 6 分後の温度を示す. 5 人の被験者による保温指標 值を図 6 に示す。横軸が各熱伝達形態, 縦軸が保温指標值である. 白丸が, 手掌部の保温指標值, 黒丸が指先部の保温指標値を示す. 手掌部においては遠赤外線放射加熱の保温指標值は他の熱伝達形 態に比べ高く，保温性に優れることが分かる，一方，指先につい ては図 5 より, 加熱停止直後の指先温度が低い影響もあり保温指 標值が高く表れたと考えている。 さらに，遠赤外線放射加熱の指 先で100以上の保温指標值を示すデー夕があるが, 手掌の温度分布 には個人差があることが報告されており ${ }^{8)}$, 今回の実験結果から も被験者ごとの個人差が表れている。この被験者の初期指先温度 


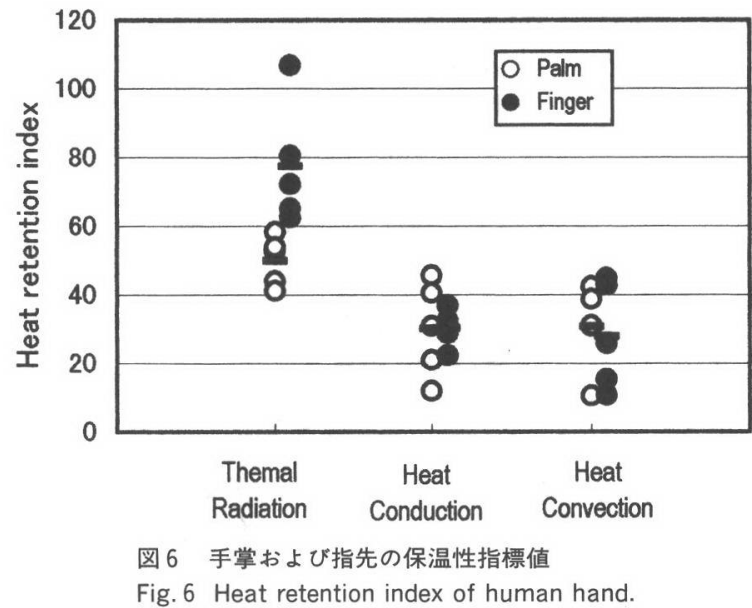

が低かったため, 相対的に保温指標值が高く表れたと考えている.

\section{5 . 検討}

遠赤外線は電磁波（光）としての性質を持ち，皮膚の赤外領域 における反射率は低い9 ，そのため熱伝導や熱対流のように皮䖉 表面に直接熱工ネルギーが伝達されるのではなく皮膚内部で熱工 ネルギーに変換される ${ }^{10)}$. よって皮膚内部において生ずる熱工ネ ルギーが皮䖉により保温されている可能性がある。また, 透過吸 収の過程で皮膚内部器官の活性化作用を及ぼすことも考えられ る. 皮䖉には温度受容器が存在し, それは表面より数百 $\mu \mathrm{m}$ の ころに存在すると想定されている ${ }^{11)}$. 温度受容器で検知された情 報は脊髄, 延䯣, 中脳, 視床下部に伝達され体温調節反応として 血管調節反応が行われる ${ }^{12)}$.つまり, 手掌に照射され透過した遠赤 外線が皮䖉の温度受容器を介して体温調節機能を活性化させ，血 管拡張反応が生じていると考えられる。血管の拡張は血流量を増 大させるため保温効果につながる。遠赤外線を照射していない指 先の保温性も良好だったのは, 手掌部に大きなカーブを描いて延 びている掌動脈から枝別れした指動脈 ${ }^{13)}$ が手掌部の血管拡張の影 響を受けた事を示す。

\section{6.まとめ}

本報告では天然鉱物粉末の混合により安価で簡便に，面積の広 い高分光放射率遠赤外放射体の作製を試み，その遠赤外線放射体 により遠赤外線放射の人体の保温性についての有用性について検 討した。以下に本論文で得られた成果を要約する。

（1）ゼオライト, パーライトの 2 種の天然鉱物粉末を耐熱バインダ 一とともに混合し金属板に塗布し，接着することで，広面積の 高分光放射率を有する遠赤外線放射体を安価に簡便に作製する 方法を構築した.

（2）遠赤外線放射，熱伝導，熱対流の各熱伝達形態による加熱後の 人体の手掌および指先の温度変化を比較したところ, 遠赤外線 放射の保温性が高いことが明らかになった。

現在, $120 \mathrm{~mm} \times 120 \mathrm{~mm}$ の大面積を有する遠赤外線放射体を作製し， 放射体サイズを変えた場合の保温性の検討を進めている.さらに, 血流量の変化と発汗および保温性の関係を調査中である.

今後の課題としては次の 2 点があげられる.

(1) 他の放射体（セラミクスや市販放射体）との保温性の比較.

（2）各熱伝達形態での手掌への投入エネルギーを一定とした時の 保温性の比較.
本研究を進めるにあたり多大な貢献をした研究室卒業生石川誠 君に謝意を表する。また, 本研究の一部は, 文部科学研究費（地 域連携11792019）により行った.

\section{参 考 文 献}

(1) 赤外線技術研究会：赤外線工学, オーム社, pp.232-237 (1991).

(2) 吉村昇, 松本丞二, 佐々木芳弘, 田口春男：天然ゼオライト の遠赤外放射特性，照学誌，75-10, pp.577-581 (1991).

(3) 吉村昇, 松本丞二, 佐々木芳弘, 田口春男 : 天然ゼオライト の遠赤外放射特性とその加熱効果, 秋田大学鉱山学部資源地 学研究施設報告, 56, pp.181-185 (1991).

(4) 地学団体研究会地学事典編集委員会：地学事典, 平凡社, p. 46 (1992).

(5) 富永博夫：ゼオライトの科学と応用, 講談社, pp.1-39 (1991).

（6）進藤隆世志, 猿田直子, 中田竜, 山崎達也, 北林茂明, 小沢 泉太郎：窒素およびメタンをプローブとする天然ゼオライ トの吸着特性，素材物性学会誌，14，1/2，pp.6-11 (2001).

（7）世界大百科事典，平凡社， $23 ，$ p.46 (1998).

(8) Hideyuki KOKUBO, Junko TANIGUCHI, Masahiko HIRASAWA and Mikio YAMAMOTO : Basic Thermal Distribution for the Hand of Ordinary Persons, J. Intl. Soc. LifeInfo. Sci, 16-2, pp.247-251 (1998).

(9) Th. J. J. A, Manders: The "infraphil" an Apparatus for Infr-red Therapy, Philips Technical Review, 8, 6, pp.177 -182 (1946).

(10) 松井松長：遠赤外放射利用の問題点と将来展望, 照学誌, 74 -12, pp.5-8 (1990).

(11) 大山正, 今井省吾, 和氣典二 : 新編 感覚・知覚ハンドブッ ク, 誠信書房, p.1197 (1994).

（12）山田幸生，棚澤一郎，谷下一夫，横山真太郎：からだと熱と 流れの科学, オーム社, p.46 (1998).

(13) 藤田恒太郎：人体解剖学, 南江堂, p.295 (2000).

（受付日2001年 7 月 23 日 /採録日 2002 年 4 月 12 日）

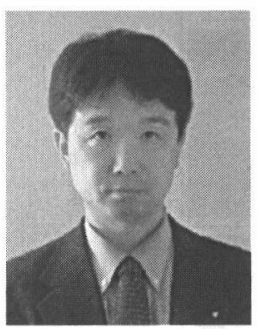

田口 春男 (非会員)

TDK 株式会社

1956年生. 秋田大学鉱山学部電気工学科卒 業, 1978年 TDK 株式会社入社, 以来, 主にセ ラミックの材料開発に従事. 